\title{
ANTÔNIO JOSÉ E O TEATRO DO SETECENTOS
}

\author{
Iná Camargo Costa ${ }^{1}$
}

\section{Resenha}

JUNQUEIRA, Renata Soares; MAZZI, Maria Gloria Cusumano (Orgs.). O Teatro no Século XVIII: Presença de Antônio José da Silva, o Judeu. São Paulo: Editora Perspectiva, 2008. (Coleção Estudos, 256).

Nas lembranças aniversárias brasileiras de Antônio José da Silva, o ano de 2005 marca uma auspiciosa peripécia. O centenário de sua prisão e execução foi rememorado com a estreia da primeira tragédia do teatro brasileiro, Antônio José ou O Poeta e a Inquisição em 1838, seguida da publicação do texto de Gonçalves de Magalhães em 1839. Em 1940, a biografia de Cândido Jucá Filho, Antônio José, o Judeu, não deixou o bicentenário passar em branco. Registre-se, ainda, que em 1944 também o bicentenário da publicação de sua obra foi discretamente comemorado entre nós por uma reedição dos dois volumes de suas Óperas. Mas parece ter sido no ano de 2005 que, finalmente e trezentos anos depois, teve início a celebração, não mais da morte, mas do nascimento do nosso comediógrafo. Merecem destaque pelo menos dois eventos: nesse ano foi realizada a IV Semana de Estudos Teatrais da UNESP em sua homenagem, e reeditada a tragédia de Gonçalves de Magalhães em volume preparado por Mariângela Alves de Lima. A publicação em 2008, pela editora Perspectiva, do livro O teatro no século XVIII: presença de Antônio José da Silva, o Judeu, organizado por Renata Soares Junqueira e Maria Gloria Cusumano Mazzi, traz a público o material apresentado na Semana de 2005. 
Sem desprezar o vil garrote mental a que estivemos submetidos nos três primeiros séculos de colonização pela censura a cargo da Igreja Católica Romana e seu "Santo Ofício", é de se pensar se o peso da formação católica forçada, que combina culpa e contrição diante da morte, também não terá impedido o nosso mundo acadêmico e teatral de se voltar há mais tempo para o que realmente interessa quando o assunto é comédia: a vida, a obra, o humor e o espírito crítico. Mas deixemos o inventário dos necrológios para os especialistas e tratemos da novidade representada pelo livro em tela.

Dividido em duas partes, a primeira é uma espécie de prólogo com quatro ensaios que armam um amplo panorama das nossas práticas teatrais nos tempos da colônia e das mudanças experimentadas pelo teatro europeu dos séculos XVI a XIX, enquanto a segunda tem sete ensaios dedicados à vida e obra de Antônio José.

As notícias de Ana Portich sobre os esforços da igreja contrarreformista para conter os avanços do teatro em diversos países europeus, a começar pela própria Itália, ajudam a entender pelo menos um aspecto da perseguição a Antonio José, mas contêm um alerta adicional sobre esta luta que atravessou o século XVIII, que não se restringia aos padres e que ainda não está encerrada: tratava-se, então como agora, de preservar e cultivar a dependência e a tutela mental. Exemplo aterrador de tal disposição encontra-se em texto do conde veneziano, Carlo Gozzi, concorrente de Goldoni na segunda metade do século: "não é tirania, mas caridosa e madura prudência acostumar os povos, tanto quanto possível, a essa simplicidade que de forma alguma denomino ignorância; ao contrário, tirano furioso é aquele que, tentando infundirlhe sofismas e uma perigosa soberba, os inquieta e os expõe aos funestos e necessários castigos de quem governa."

1 Professora aposentada da Universidade de São Paulo, na Faculdade de Filosofia, Letras e Ciências Humanas; Departamento de Teoria Literária e Literatura Comparada.
Por "perigosa soberba" entenda-se aquilo que os iluministas chamavam "pensar por conta própria", crime inafiançável para a Inquisição, pelo qual Antonio José pagou com a vida. Quanto a "acostumar os povos à simplicidade", é só examinar o papel que vem desempenhando a indústria cultural, esta legítima herdeira de Gozzi nos séculos XX e XXI.

Roberta Barnimostraque, sem paradoxo especial, Gozzi defendia o programa de cultivar a humildade das suas ovelhas, através do teatro, exumando aspectos do que tinha sido a experiência da commedia dell'arte, numa situação em que esta já não era ameaça para mais ninguém. Na altura, seus herdeiros em sentido próprio (e não meramente formal, nem usurpadores) já estavam combatendo, principalmente na França, para assegurar a vigência de suas bandeiras, que culminaram na Revolução de 1789, com Diderot à frente.

Em direção oposta vem o balanço das marchas e contramarchas do teatro setecentista francês, apresentado por Guacira Marcondes Machado. Inteiramente sintonizado com os balanços franceses de fins do século XIX, demonstra que o século XVIII pouco acrescentou às conquistas literárias de Racine e Molière, ambos do XVII. E, do naufrágio setecentista, junto com Beaumarchais, salva-se apenas Marivaux, o inimigo dos philosophes, que foi contemporâneo do nosso Antônio José. Para esta autora, o teatro francês só haveria de recuperar-se por ocasião do romantismo.

O ensaio que abre o livro, de Antônio Donizeti Pires, também adota o romantismo comoréguaecompasso.Passandoatémesmo pelo resgate das encenações brasileiras da obra de Antônio José (por exemplo: no teatrinho de Chica da Silva, no Arraial do Tijuco), apresenta uma releitura das teorias brasileiras sobre a situação do teatro (e da literatura) por estas plagas nos tempos coloniais. Duas conclusões entrelaçadas se apresentam como proposta para debate. A principal é que na segunda metade do século XVIII já estava configurado o 
sistema teatral brasileiro e, apesar de serem poucos os registros, segue-se que a nossa diferença em relação ao sistema europeu também já estava posta: trata-se da maneira especial de misturar tudo, resultante da devoração antropofágica que no século $\mathrm{XX}$ foi transformada em escola, fundada por nosso modernista Oswald de Andrade.

Os ensaios de J.Guinsburg e Alberto Dines desenvolvem a mesma ideia em abordagens diferentes, a saber: a sentença de heresia e apostasia aplicada ao nosso comediógrafo esconde uma covardia adicional da Inquisição. Evidentemente tratou-se de calar uma voz de peralta e gozador que obstinadamente expunha, carregando nas tintas cômicas, a uma esfera pública (burguesa) - mesmo que reduzida e confinada pela censura - informações que a "boa sociedade" (aristocrática) estava cansada de conhecer: a violência dos cárceres do Santo Ofício, a parcialidade da "justiça", a incontinência sexual do rei e de suas favoritas, a parlapatice de nobres e intelectuais e assim por diante.

Todos os demais ensaios são dedicados a diferentes aspectos das comédias do nosso peralta: Francisco Maciel Silveira, ele mesmo parodiando o recurso à "questão bizantina", trata das condições materiais de produção do teatrinho de bonifrates para o qual Antônio José escrevia, assim como do interesse pela publicação de suas peças; Patrícia da Silva Cardoso, sem esquecer da liberdade vigiada de que desfrutou o comediógrafo, joga luz sobre os horrores que as comédias encobrem; Flávia Maria Corradin, centrando-se no exame do Anfitrião, traça a genealogia do tema desde a mitologia grega e seu possível primeiro tratamento por Plauto para chegar à originalidade (muito lusitana e lisboeta) de Antônio José; Maria João Brilhante dá preciosas notícias de duas encenações em 2004 de comédias deste autor, que em Portugal é considerado um clássico: uma com atores e outra com atores, bonecos e atores-bonecos.

Encerrando os trabalhos, Paulo Roberto Pereira traz uma notícia importante para dimensionar o quanto ainda temos que esperar das pesquisas para chegarmos a uma ideia mais aproximada do que foi a experiência teatral de Antônio José. Embora designadas como óperas, só muito recentemente (anos 40 do século $\mathrm{XX}$ ) os especialistas descobriram as partituras das suas comédias. Isto significa que, salvo pelas apresentações do século XVIII, sempre foram considerados apenas os textos para avaliar a importância de Antônio José. Agora que já estão disponíveis algumas das partituras, e que já se conhece a sua autoria (padre Antônio Teixeira), Paulo Roberto Pereira tem material para afirmar que, com Antônio José, o teatro português explorava o mesmo terreno que John Gay vinha explorando desde 1728 na Inglaterra, com sua Ópera do mendigo, e que Mozart, no império austríaco, viria a explorar com obras como A flauta mágica (1791). Diante de tais informações e das que Maria João Brilhante já nos traz sobre os experimentos portugueses (um dos espetáculos por ela comentados usou até uma gravação de Only you para dar conta do espectro musical, evidentemente radicalizando a pândega), nada nos impede de esperar que, mais dia, menos dia, apareça uma dupla como Brecht e Weill para fazer com qualquer das óperas de Antônio José o mesmo que os alemães fizeram com a ópera de John Gay. Meu voto vai para Guerras do alecrim e manjerona, para homenagear o fino olfato de Semicúpio, que reage mal ao cheiro da procissão de ramos. 